\title{
Effects of particle sizes of rock phosphate on immobilizing heavy metals in lead zinc mine soils
}

\author{
Z. Zhao ${ }^{1,2^{*}}$, G. Jiang ${ }^{1}$, R. Mao ${ }^{1}$
}

${ }^{I}$ School of Land Science and Technology, China University of Geosciences, Beijing 100083, P. R. China. ${ }^{2}$ Key Laboratory of Land Consolidation and Rehabilitation, Ministry of Land and Resources, Beijing 100083, P. R. China. Corresponding author: zqzhao@cugb.edu.cn

\begin{abstract}
Phosphate-induced immobilization is recognized as one of effective in situ remediation methods for heavy metal contaminated soils. Phosphate-based minerals that adsorb, chelate, or complex heavy metals in soil were greatly concerned as effective heavy metals immobilizing materials. Effects of particle sizes of rock phosphate on immobilizing heavy metals in $\mathrm{Pb}-\mathrm{Zn}$ mine soils by a greenhouse experiment was conducted. Rock phosphate was added to a $\mathrm{Pb}-\mathrm{Zn}$ mine soil with four different particle sizes, D97<101.43 $\mu \mathrm{m}$ (UP), D97<71.12 $\mu \mathrm{m}$ (P1), $\mathrm{D} 97<36.83 \mu \mathrm{m}(\mathrm{P} 2)$ and D97<4.26 $\mu \mathrm{m}$ (P3) (the diameters of $97 \%$ of the particles were less than $4.26 \mu \mathrm{m}$.), and 2 rates $(2.5 \%$ and $5 \%)$. Lolium prenne, L. were grown in the treated soils. Compared to the control, addition of rock phosphate (RP) decreased metal contents in both roots and shoots significantly. $\mathrm{Pb}$ contents in shoots decreased by $19.59 \%-37.80 \%$ by different particle sizes at the rate of 5\%, reaching lowest level at lowest particle size P3. $\mathrm{Zn}$ contents in shoots decreased by $13.47 \%-13.75 \%, \mathrm{Cu}$ in roots was decreased by $18.46 \%-67.98 \%$ and in shoots by $16.82 \%-32.61 \%$, and $\mathrm{Cd}$ in roots decreased by $31.03 \%-74.23 \%$. The results indicated that, RP can reduce the phytoavailability of $\mathrm{Pb}, \mathrm{Zn}, \mathrm{Cu}$ and $\mathrm{Cd}$ in soil significantly by immobilization and the effects strengthened with the decrease of particle size and increasing the rate of addition.
\end{abstract}

Keywords: Particle size, rock phosphates (RP), immobilization, heavy metals, $\mathrm{Pb}-\mathrm{Zn}$ mine soil

\section{Introduction}

Heavy metal contamination of soil is a widespread global problem. Contaminated soil can be remediated by physical, chemical or biological techniques Generally, these techniques can be classified to two remediation strategies- extraction or stabilization. Stabilization is cost-effective and less disruptive to the soil and the environment. Stabilization of contaminants in soil can be achieved by addition of immobilizing amendments which are able to decrease metal leaching and bioavailability by inducing various sorption processes: adsorption to mineral surfaces, formation of stable complexes with organic ligands, surface precipitation and ion exchange (Kumpiene et al., 2008).

Phosphorus-containing amendments were greatly concerned amendments on in situ remediation of metal contaminated soils. Most of the studies were 
performed on stabilizing $\mathrm{Pb}$ in soils and mineral rock phosphate (RP) was particularly concerned because of its cost-effectiveness and less disruptive nature (Ma et al., 1997; Hettiarachchi and Pierzynski, 2002; Cao et al., 2004; Ownby et al., 2005; Chen et al., 2006; 2007; 2009), and the possible mechanisms of RP stabilizing $\mathrm{Pb}$ was suggested as a process including ion exchange processes at the surface of RP, surface complexation, and replacement of $\mathrm{Ca}$ in $\mathrm{RP}$ by $\mathrm{Pb}$ (Takeuchi and Arai, 1990; Jeanjean et al., 1994; Ma et al., 1995; Basta et al., 2001; Geebelen et al., 2002; Cao et al., 2004) with formation of pyromorphite-type minerals $\left[\mathrm{Pb}_{5}\left(\mathrm{PO}_{4}\right)_{3} \mathrm{X}\right.$; $\mathrm{X}=\mathrm{F}, \mathrm{Cl}, \mathrm{B}$ or $\mathrm{OH}]$. For example, the formation of stable fluoropyromorphite $\left[\mathrm{Pb}_{10}\left(\mathrm{PO}_{4}\right) 6 \mathrm{~F} 2\right]$ was the main mechanism responsible for $\mathrm{Pb}$ stabilization in soil amended with RP containing $F$ which dominated over surface sorption/complexation reactions(Cao et al., 2004).

Rock phosphate can also remove $\mathrm{Zn}$ and $\mathrm{Cu}$ from aqueous solutions (Xu et al., 1994; Brown et al., 2005). Cao et al. (2004) reported that sorption capacity of RP in multi-contaminated soil is in the order of $\mathrm{Pb}>\mathrm{Cu}>\mathrm{Zn}$ with sorption capacities of 138,114 , and $83.2 \mathrm{mmol} / \mathrm{kg}$ RP, respectively. Similarly, study of Saxena and D'Souza (2006) showed that adsorption of heavy metal ions to RP was found to follow the order: $\mathrm{Pb}^{2+}>\mathrm{Cu}^{2+}>\mathrm{Zn}^{2+}>\mathrm{Co}^{2+}$. Thawornchaisit and Polprasertb (2009) investigated the stabilization of $\mathrm{Cd}$ in highly contaminated soils by different phosphate fertilizers, RP decreased the leachable $\mathrm{Cd}$ concentrations and the mobile forms of $\mathrm{Cd}$ in the contaminated soils as evidence by the TCLP and the sequential extraction tests.

The stabilization efficiency varied depending on types of fertilizers which appears to correlate with dissolution of fertilizer (Zenteno et al., 2013). Application of synthetic hydroxyapatite (HA) and natural rock phosphate $(\mathrm{RP})$ in heavy metal $(\mathrm{Cd}, \mathrm{Cu}, \mathrm{Pb}$, and $\mathrm{Zn})$ contaminated soil effectively reduced the heavy metal water solubility generally by about $84-99 \%$ with HA showing slightly superior to RP for immobilizing heavy metals (Mignardi et al. 2012). Study of Mignardi et al. (2013) on Co and Ni showed that, the application of phosphate amendments to the polluted mine waste soils reduced water-soluble concentrations of Co and Ni by about $99 \%$, and RP was slightly less effective than HA in immobilizing Co and Ni. However, Cao et al. (2009) found that, although RP reduced plant $\mathrm{Cu}$ and $\mathrm{Zn}$ concentrations in two contaminated soils, the $\mathrm{Cu}$ and $\mathrm{Zn}$ phytoavailability generally was little affected except for some treatments.

Although the soluble-P treatment has often been shown to immobilize heavy metals effectively in soils, the secondary environmental risk of the use of soluble $\mathrm{P}$ as a soil amendment may be unavoidable due to the possibility of $\mathrm{P}$ leaching leading to eutrophication (Basta and McGowen 2004; Park et al. 2011a; Mignardi et al., 2012; 2013). On this hand, soluble P sources may not be suitable for the remediation of heavy metals, especially in low P-retaining sandy soils (Park et al. 2012). Instead of soluble P, less soluble RP can reduce the risk of phosphate-induced eutrophication (Park et al. 2012; Mignardi et al. (2013).

The possible mechanisms for heavy metal immobilization in the soil involve both surface complexation of the metal ions on the phosphate grains and partial dissolution of the phosphate amendments and precipitation of heavy metal-containing phosphates (Mignardi et al., 2012). Based on the possible mechanisms, the surface area and solubility of RP in soil solution determine the efficiency of stabilization. Three procedures can enhance heavy metals immobilization by RP: 1) adding phosphatesolubilizing bacteria (Park et al. 2011b), 2) increasing the addition rate and 3 ) reducing the particle size of RP (Chen et al. 2006). Chen et al. (2006) suggested that rock phosphate with smaller grain size was more effective to lower the bioavailability and increase the geochemical stability of metals in soil than larger size. The aim of this study is to investigate the effects of $\mathrm{RP}$ particles size on immobilizing $\mathrm{Pb}, \mathrm{Zn}, \mathrm{Cu}$ and $\mathrm{Cd}$ in lead zinc mine soils by means of a greenhouse experiment. In lead zinc mine, $\mathrm{Cd}$ and $\mathrm{Cu}$ are usually accompanied contaminants, so our research included the heavy metal $\mathrm{Cd}$ and $\mathrm{Cu}$ beside $\mathrm{Pb}$ and $\mathrm{Zn}$. 


\section{Materials and Methods}

\subsection{Soils}

The soil used was collected from the Shuikoushan $\mathrm{Pb} / \mathrm{Zn}$ mine area in Songbai town, Hengyang, Hunan province (China). Surface soil $(0-20 \mathrm{~cm})$ was excavated and collected and transported to the laboratory. The soil sample was air-dried, homogenized and sieved to a $<2 \mathrm{~mm}$ with stainless steel mesh prior to use for physical and chemical properties analysis and pot experiment.
Soil $\mathrm{pH}$ (soil : water; $1: 2.5$ ) was determined by a combination electrode. The properties of the soils were determined according to standard methods recommended by the Chinese Society of Soil Science ( $\mathrm{Lu}, 1999)$. Total concentrations of metals $(\mathrm{Cd}, \mathrm{Pb}, \mathrm{Zn}$ and $\mathrm{Cu})$ were determined using digestion of soil sample $(0.2 \mathrm{~g})$ in $5 \mathrm{~mL}$ of $\mathrm{HNO}_{3} / \mathrm{HClO}_{4}$ (3:1) diluted to a volume of $25 \mathrm{ml}$ with distilled water, and measured by inductively coupled plasma spectrometry (ICP-OES, Varian 715 ES, USA). Some basic physiochemical properties and metal contents of the soils are listed in Table 1.

Table 1. Cation exchange capacity (CEC), $\mathrm{pH}$, Organic carbon (OC, \%), and heavy metals contents of studied soils.

\begin{tabular}{ccccccc}
\hline $\mathrm{pH}$ & $\begin{array}{c}\mathrm{CEC} \\
\left(\mathrm{cmol} \cdot \mathrm{kg}^{-1}\right)\end{array}$ & $\begin{array}{c}\mathrm{OM} \\
(\%)\end{array}$ & $\begin{array}{c}\mathrm{Pb} \\
\left(\mathrm{mg} \cdot \mathrm{kg}^{-1}\right)\end{array}$ & $\begin{array}{c}\mathrm{Zn} \\
\left(\mathrm{mg} \cdot \mathrm{kg}^{-1}\right)\end{array}$ & $\begin{array}{c}\mathrm{Cu} \\
\left(\mathrm{mg} \cdot \mathrm{kg}^{-1}\right)\end{array}$ & $\begin{array}{c}\mathrm{Cd} \\
\left(\mathrm{mg} \cdot \mathrm{kg}^{-1}\right)\end{array}$ \\
\hline 4.85 & 8.08 & 2.41 & 881.64 & 1065.97 & 113.08 & 16.92 \\
\hline
\end{tabular}

\subsection{Design}

Mineral RP (20\% P content) was provided by Yunnan Phosphorization Group Co. Ltd., China. The sample of RP was grind by air-flow disintegrator (QLD, Pinzhen Facility Technology Co. Ltd, Shanghai) and the particle sizes were determined by Centrifugal Sedimentation Particle Size Analyzer (BT-1500, Baitai Co. Ltd). The RP was ground and divided into 4 sizes: D97<101.43 $\mu \mathrm{m}$ (UP), D97<71.12 $\mu \mathrm{m}$ (P1), D97<36.83 $\mu \mathrm{m}(\mathrm{P} 2)$ and $\mathrm{D} 97<4.26 \mu \mathrm{m}(\mathrm{P} 3)$ (the diameters of $97 \%$ of the particles were less than $4.26 \mu \mathrm{m}$.), respectively. Every size of the RP was applied at $2.5 \%$ and $5 \%$. Soil without RP addition was used as the control (CK). So all together there are 9 treatments: $\mathrm{CK}, 2.5 \mathrm{UP}, 2.5 \mathrm{P} 1,2.5 \mathrm{P} 2,2.5 \mathrm{P} 3$, 5UP, 5P1, 5P2, 5P3. Nutrients were provided by uniform $\mathrm{N}-\mathrm{K}$ fertilizer application at amounts equal to $100 \mathrm{mg} \mathrm{N} / \mathrm{K} \mathrm{kg}^{-1}$ soil. Each treatment had four replicates. The treated soils were mixed thoroughly and taken into plastic pots $(1 \mathrm{~kg} / \mathrm{pot})$ and saturated with deionized water. Soil was allowed to equilibrate in the greenhouse for 1 week before sowing the seeds.

Fifty germinated seeds of perennial ryegrass (Lolium prenne, L.) were planted in each pot. The pots were randomly arranged in the greenhouse and rearranged several times during the growth period. When the seedlings had grown to about $3 \mathrm{~cm}$, they were thinned to twenty per pot. The seedlings were watered to weight to maintain $100 \%$ field capacity of each type of soil every 2 days. The mean growth temperature was $25{ }^{\circ} \mathrm{C}$ during $14 / 10 \mathrm{~h}$ light/dark cycle. The seedlings were harvested after 3 months.

\subsection{Plant analysis}

After harvest, the seedlings were separated into shoots and roots and rinsed thoroughly with deionized water, and the fresh weights were determined. The samples were then oven dried at $70{ }^{\circ} \mathrm{C}$ for $48 \mathrm{~h}$, and the dry weight (DW) of shoots and roots was recorded. Dried 
plant samples were finely ground in a stainless steel miller. Subsamples $(0.25 \mathrm{~g})$ of finely ground plant materials were digested in $5 \mathrm{ml}$ high-purity acid $\mathrm{HNO}_{3}$ at $160{ }^{\circ} \mathrm{C}$. The digest was diluted to $25 \mathrm{ml}$ using high purity water, and the concentration of $\mathrm{Pb}, \mathrm{Zn}, \mathrm{Cu}$ and $\mathrm{Cd}$ in the digest was determined by inductively coupled plasma mass spectrometry (ICP-OES, Varian 715 ES, USA).

\subsection{Statistical analysis}

All data of biomass, $\mathrm{pH}$ and Heavy metal contents in tissue were subjected to the analysis of variance (ANOVA) with a Duncan test at $95 \%$ confidence by SPSS 18.0. Differences at the $p<0.05$ level were considered to be significant.

\section{Results and Discussion}

\subsection{Plant shoot biomass}

Addition of RP increased shoot biomass significantly by $200-816 \%$ compared to the control except for $2.5 \mathrm{UP}$ $(p<0.05)$ (Figure 1), which was in agreement with the reports of Chen et al. $(2006 ; 2009)$ and Mignardi et al. (2012). Results of Mignardi et al. (2012) showed that, compared to the control, both soluble and insoluble $\mathrm{P}$ (RP) treatments significantly increased shoot and root weight of sunflower (Helianthus annuus).Shoot dry weight increased by $31.5 \%, 32.9 \%$, and $54.1 \%$ for RP.

$5 \%$ level of RP promoted significantly shoot biomass than $2.5 \%$ level except for $2.5 \mathrm{P} 3(p<0.05)$. At the same RP level, the application of smaller particle size resulted in a higher biomass than larger particle size, especially the smallest size P3 (D97< $4.26 \mu \mathrm{m}$ ) $(p<0.01)$ (Figure1). The result may be due to two reasons. On the one hand, addition of RP increased the P fertilizer level for plant growth, and on the other hand, addition of RP which immobilize heavy metals in the soil may result in low accumulation of heavy metals in plant reducing their phytotoxicity (Chen et al., 2009). The improved growth observed after addition of the smallest size P3 of RP suggested that $\mathrm{P} 3$ fraction reduced more effectively phytotoxicity of heavy metals with respect to the other fractions.

\subsection{Soil $p H$}

$\mathrm{RP}$ addition slightly affected soil $\mathrm{pH}$ (Figure 2). Except for 2.5UP, soil $\mathrm{pH}$ was increased by different RP rates and particle sizes. At the rate of $2.5 \%$, addition of $\mathrm{P} 1$ and $\mathrm{P} 2$ increased soil $\mathrm{pH}$ by around 0.21 and 0.22 units compared to the control $(p<0.05)$. The results were in agreement with reports of Tang et al. (2004) and Chen et al. (2007). Tang et al. (2004) added RP at the level of $5000 \mathrm{mg} \mathrm{P} \mathrm{kg}^{-1}$ to the soil resulted in soil $\mathrm{pH}$ increased slightly by around 0.1 unit. Chen et al. (2007) reported the soil $\mathrm{pH}$ increased due to the addition of $\mathrm{RP}$ and HA. This may be due to much $\mathrm{CaCO}_{3}$ contents in RP which makes it as alkaline characteristic (Zhu et al., 2004). On the contrary, the application of soluble $\mathrm{P}$ amendments such as triple super phosphate (TSP), super phosphate (SSP) and diammonium phosphate (DAP) was reported to decrease soil pH (Chen et al., 2007). This effect may induce soil acidic conditions and increase heavy metal solubility. Therefore, the use of less soluble P for immobilization of heavy metals may be more environmentally friendly considering soil condition.

\subsection{Heavy metal contents in tissue}

Addition of $\mathrm{RP}$ reduced $\mathrm{Pb}$ contents in both roots and shoots significantly except for 2.5UP treatment $(p<0.01)$ (Figure $3 \mathrm{~Pb}$ ). The concentration of $\mathrm{Pb}$ decreased with the decreasing of particle size and increasing application rate. 2.5UP has largest particle size and low application level which may result in nonsignificant effect compared to the other treatments. $\mathrm{Pb}$ contents in shoots reached the lowest level at 5P3 treatment, with a reduction of $54.9 \%$ compared to the control. Consistent with the results of previous studies by Chen et al. (2009), most of the Pb mainly accumulated to a greater extent in the roots which were 6.6-9.0 folds higher than that in shoots (Figure $3 \mathrm{~Pb}$ $\mathrm{B} / \mathrm{A})$. 


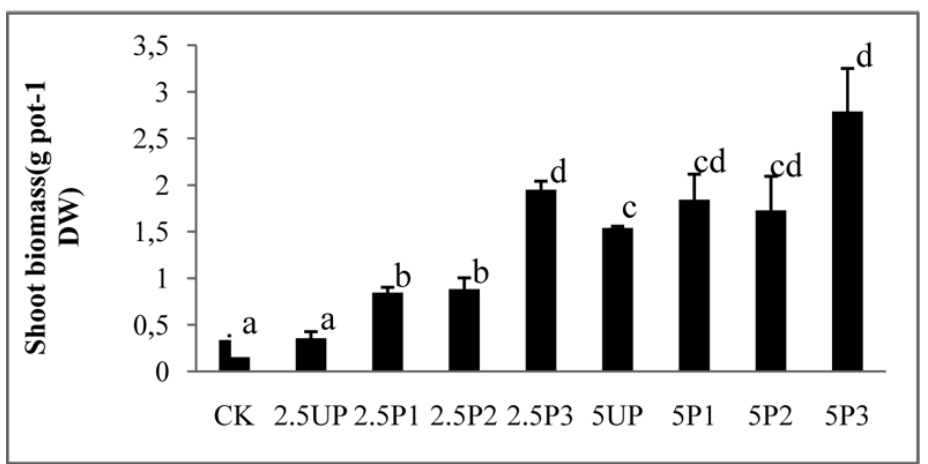

Figure 1. Shoot biomass of ryegrass grown in heavy metal contaminated soils treated with different PR levels and particle sizes. Vertical bars represent standard deviations $(n=4)$.

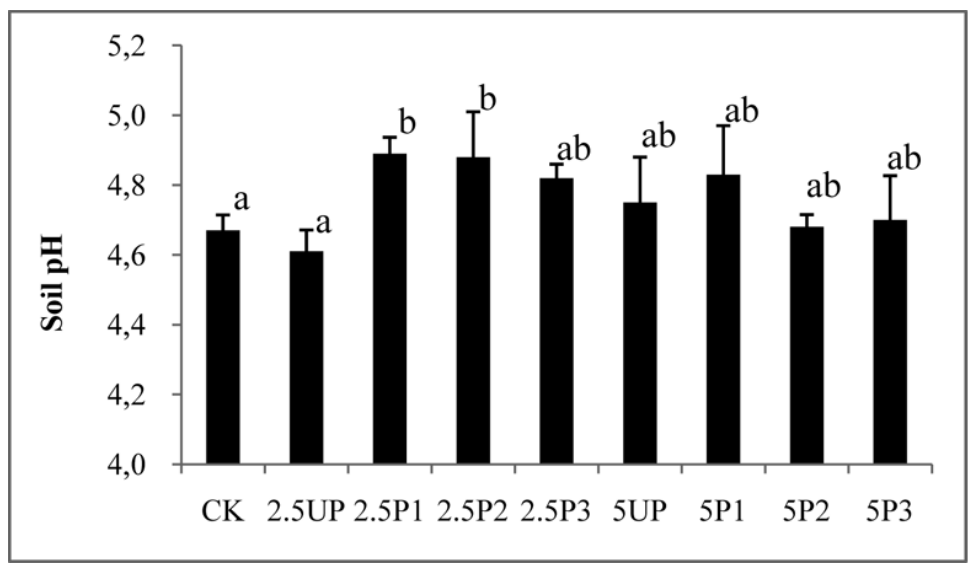

Figure 2. Soil $\mathrm{pH}$ with different $\mathrm{PR}$ levels and particle sizes treatment. Vertical bars represent standard deviations $(n=4)$. 

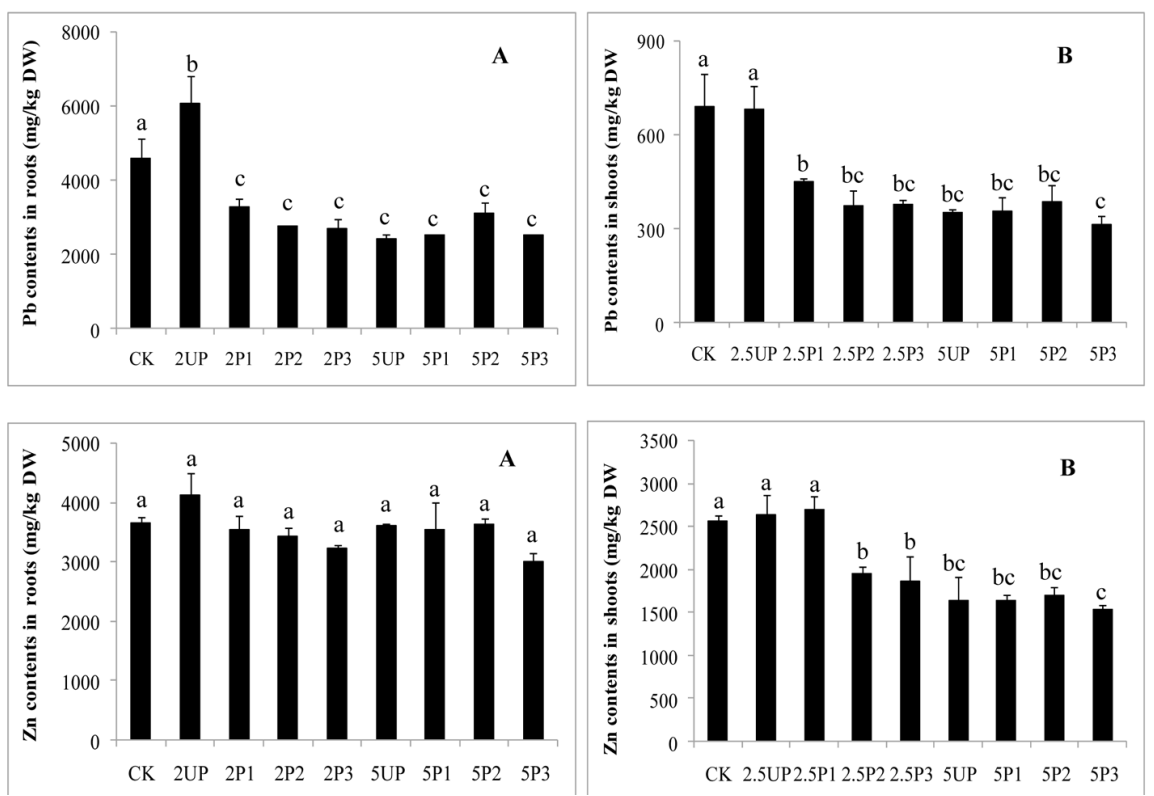

Figure 3a. Heavy metal contents in roots (A) and shoots (B) of ryegrass grown in heavy metals contaminated soils treated with different PR levels and particle sizes. Vertical bars represent standard deviations $(n=4)$.
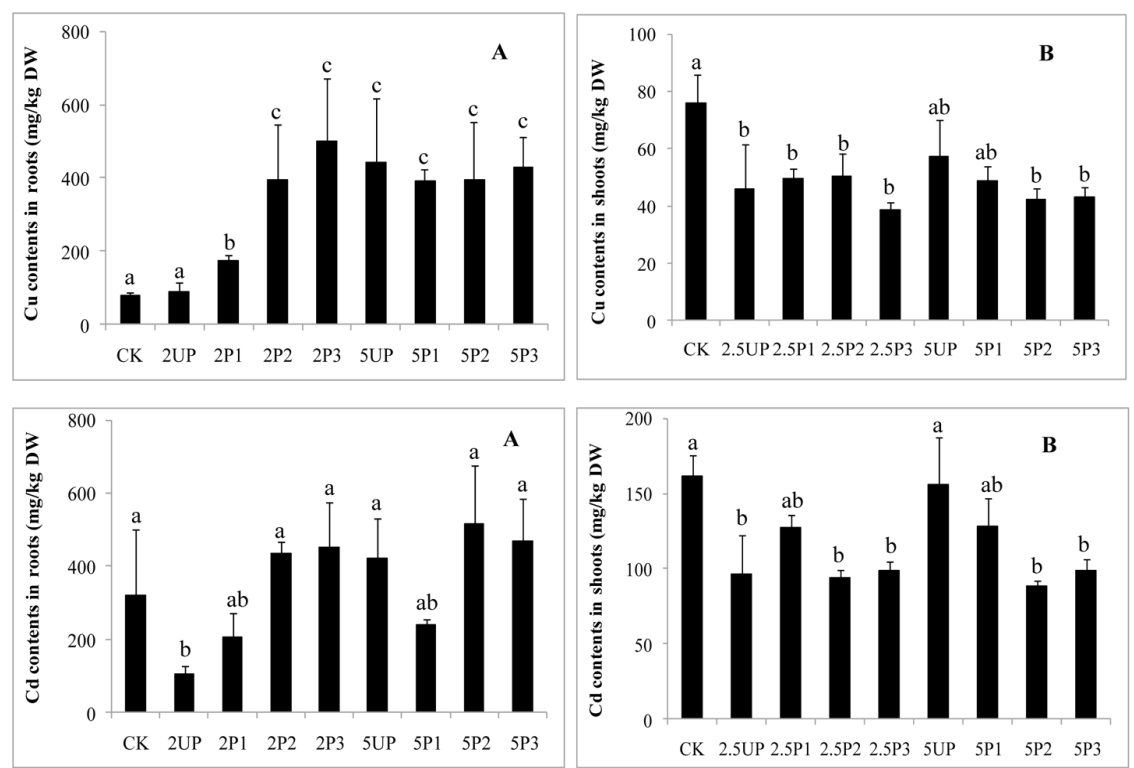

Figure 3b. Heavy metal contents in roots (A) and shoots (B) of ryegrass grown in heavy metals contaminated soils treated with different PR levels and particle sizes. Vertical bars represent standard deviations $(n=4)$. 
$\mathrm{Zn}$ contents in shoots were reduced significantly by addition of RP except 2.5 UP and 2.5P1, and reached the lowest level at $5 \mathrm{P} 3$ which was decreased by $40 \%$ (Figure $3 \mathrm{Zn} \mathrm{A}$ ). However, there's no significant change of $\mathrm{Zn}$ contents in roots (Figure $3 \mathrm{Zn} \mathrm{B}$ ). For $\mathrm{Cu}$, addition of RP reduced the shoot $\mathrm{Cu}$ contents significantly compared to the control, and the effects were more remarkable with smaller particle sizes. However, no statistically significant variance between the two RP addition levels has been observed. In the roots, interestingly, addition of RP increased the root $\mathrm{Cu}$ contents. The shoot $\mathrm{Cd}$ contents in lower particle size (P1 and P2) were decreased significantly, with $45 \%$ and $39 \%$ decreased at 5P2 and 5P3 treatment respectively. Root $\mathrm{Cd}$ contents decreased significantly by addition of $\mathrm{RP}$ at some treatments but not showing a regular pattern.

This mineral was shown to be highly stable under a wide range of $\mathrm{pH}$ (3-9). Study of Basta and McGowen (2004) showed that, Layered RP at $180 \mathrm{~g} \mathrm{~kg}^{-1}$ showed 99.9\% reduction in $\mathrm{Pb}$ eluted compared with the untreated check, but was less effective in reduction of eluted Cd (53\%) and Zn (24\%). While RP mixed with soil at 60 and $180 \mathrm{~g} \mathrm{~kg}^{-1}$ was generally ineffective for reducing $\mathrm{Cd}, \mathrm{Pb}$, and $\mathrm{Zn}$ elution, with only $<27 \%$ reduction. RP was also mixed with soil in our experiment treatment and the results at high particle sizes was in consistent with their results for mixed treatment, but the results at lower particle sizes showed more effective than results for high particles and results of theirs even at lower levels, clearly indicating the particle size of RP influence the effectiveness significantly for immobilizing $\mathrm{Pb}, \mathrm{Zn}, \mathrm{Cu}$ and $\mathrm{Cd}$, especially for $\mathrm{Pb}$. This may be due to the lower particle size- induced higher surface area increasing surface complexation of the metal ions on RP grains and partial dissolution of RP and consequently the precipitation of heavy metal-containing phosphates.

\section{Conclusions}

A green house pot experiment was conducted to study the effects of rock phosphates (RP) with different particle sizes on immobilizing heavy metals in contaminated soils of $\mathrm{Pb}-\mathrm{Zn}$ mine. Addition of Rock phosphate decreased metal contents in both roots and shoots of Lolium prenne L significantly and the particle sizes affect the metal contents significantly. We observed that the treatment of particles less than 4.26 $\mu \mathrm{m}$ at $5 \%$ rate was most effective with exception of $\mathrm{Zn}$ in roots and $\mathrm{Cd}$ in shoots. Our results provided the evidence that, $\mathrm{RP}$ can immobilize the $\mathrm{Pb}, \mathrm{Zn}, \mathrm{Cu}$ and $\mathrm{Cd}$ in soil and reduce their phytoavailability significantly, and the effects strengthened with the particle size lower and the rate of addition increased, which may be indirect evidence for the mechanisms of PR immobilizing heavy metals.

\section{Acknowledgements}

This research was supported by the National Natural Science Foundation of China (No. 20807039). The authors thank Dr. Huang Yizong and Dr. Du Gangxiang for experimental helps.

\section{References}

Basta, N.T., McGowen, S.L. 2004. Evaluation of chemical immobilization treatments for reducing heavy metal transport in a smelter-contaminated soil. Environmental Pollution. 127, 73-82.

Basta, N.T., Gradwohl, R., Snethen, K.L., Schroder, J.L. 2001. Chemical immobilization of lead, zinc, and cadmium in smelter-contaminated soils usingbiosolids and rock phosphate. Journal of Environmental Quality. 30, 1222-1230.

Brown, S., Christensen, B., Lombi, E., McLaughlin, M., McGrath, S., Colpaert, J., Vangronsveld, J. 2005. An inter-laboratory study to test the ability of amendments to reduce the availability of $\mathrm{Cd}$, $\mathrm{Pb}$, and $\mathrm{Zn}$ in situ. Environmental Pollution. 138, 34-45.

Cao, X.D., Ma, L.Q., Rhue, D., Appel, C.S. 2004. Mechanisms of lead, copper, and zinc retention by phosphate rock. Environmental Pollution. 131, 435-444. 
Cao, X.D., Wahbic, A., Ma, L., Li , B., Yang, Y.L. 2009. Immobilization of $\mathrm{Zn}, \mathrm{Cu}$, and $\mathrm{Pb}$ in contaminated soils using phosphate rock and phosphoric acid. Journal of Hazardous Materials. 164, 555-564.

Chen, S., Xu, M., Ma, Y., Yang, J. 2007. Evaluation of different phosphate amendments on availability of metals in contaminated soil. Ecotoxicology and Environmental Safety. 67, 278-285.

Chen, S.B., Chen, L., Ma, Y.B. 2009. Huang YZ. Can phosphate compounds be used to reduce the plant uptake of $\mathrm{Pb}$ and resist the $\mathrm{Pb}$ stress in $\mathrm{Pb}$ contaminated soils?. Journal of Environmental Sciences. 21, 360-365.

Chen, S.B., Zhu, Y.G., Ma, Y.B. 2006. The effect of grain size of rock phosphate amendment on metal immobilization in contaminated soils. Journal of Hazardous Materials. 134, 74-79.

Geebelen, W., Vangronsveld, J., Adriano, D.C., Carleer, R., Clijsters, H. 2002. Amendmentinduced immobilization of lead in lead-spiked soil: Evidence from phytotoxicity studies. Water Air and Soil Pollution. 140, 261-277.

Hettiarachchi, G.M., Pierzynski, G.M. 2002. In situ stabilization of soil lead using phosphorus and manganese oxide: Influence of plant growth. Journal of Environmental Quality. 31, 564-572.

Jeanjean, J., Vincent, U. Fedoroff, M. 1994. Structural modification of calcium hydroxyapatite induced by sorption of cadmium ions. Journal of Solid State Chemistry. 108, 68-72.

Kumpiene, J., Lagerkvist, A., Maurice, C. 2008. Stabilization of $\mathrm{As}, \mathrm{Cr}, \mathrm{Cu}, \mathrm{Pb}$ and $\mathrm{Zn}$ in soil using amendments-A review. Waste Management. 28, 215-225.

Lu, R.K. 1999. Analytical methods for soils and agricultural chemistry. China Agricultural Science and Technology Press. Beijing.
Ma, L.Q., Rao, G.N. 1997. Effects of phosphate rock on sequential chemical extraction of lead in contaminated soils. Journal of Environmental Quality. 26, 788-796.

Ma, L.Q., Logan, T.J., Traina, S.J. 1995. Lead immobilization from aqueous solutions and contaminated soils using phosphate rocks. Environmental Science \& Technology. 29, 11181126.

Mignardi, S., Corami, A., Ferrini, V. 2012. Evaluation of the effectiveness of phosphate treatment for the remediation of mine waste soils contaminated with $\mathrm{Cd}, \mathrm{Cu}, \mathrm{Pb}$, and $\mathrm{Zn}$. Chemosphere. 86, 354360 .

Mignardi, S., Corami A., Ferrini, V. 2013. Immobilization of $\mathrm{Co}$ and $\mathrm{Ni}$ in mining-impacted soils using phosphate amendments. Water Air Soil Pollut. 224, 1447-1456.

Ownby, D.R., Belden, J.B., Lotufo, G.R., Lydy, M.J. 2005. Accumulation of trinitrotoluene (TNT) in aquatic organisms: Part 1-Bioconcentration and distribution in channel catfish (Ictalurus punctatus). Chemosphere. 58, 1153-1159.

Park, J. H., Bolan, N., Megharaj, M., Naidu, R. 2011 a. Comparative value of phosphate sources on the immobilization of lead, and leaching of lead and phosphorus in lead contaminated soils. Science of the Total Environment. 409, 853-860.

Park, J. H., Bolan, N., Megharaj, M., Naidu, R. 2011 b. Isolation of phosphate solubilizing bacteria and their potential for lead immobilization in soil. Journal of Hazardous Materials. 185, 829-836.

Park, J. H., Bolan, N., Megharaj, M., Naidu, R. 2012. Relative value of phosphate compounds in reducing the bioavailability and toxicity of lead in contaminated soils. Water Air Soil Pollut. 223, 599-608. 
Saxena, S., D'Souza, S.F. 2006. Heavy metal pollution abatement using rock phosphate mineral. Environment International. 32, 199-202.

Takeuchi, Y., Arai, H. 1990. Removal of coexisting $\mathrm{Pb}^{2+}, \mathrm{Cu}^{2+}$ and $\mathrm{Cd}^{2+}$ ions from water by addition of hydroxyapatite powder, $\mathrm{pH}$ and sample conditioning effects. Journal of Chemical Engineering of Japan. 23, 75-80.

Tang, X.Y., Zhu, Y.G., Chen, S.B., Tang, L.L., Chen, X.P. 2004. Assessment of the effectiveness of different phosphorus fertilizers to remediate $\mathrm{Pb}$ contaminated soil using in vitro test. Environment International. 30, 531-537.

Thawornchaisit, U., Polprasertb, C. 2009. Evaluation of phosphate fertilizers for the stabilization of cadmium in highly contaminated soils. Journal of Hazardous Materials. 165, 1109-1113.
Xu, Y., Schwartz, F.W. Traina, S.J. 1994. Sorption of $\mathrm{Zn}^{2+}$ and $\mathrm{Cd}^{2+}$ on hydroxyapatite surfaces. Environmental Science \& Technology. 28, 14721480.

Zenteno, M.D.C.R., de Freitas, C.A., Fernandes, R.B. A., Fontes, M.P.F., Jordão, C.P. 2013. Sorption of cadmium in some soil amendments for in situ recovery of contaminated soils. Water Air Soil Pollut. 224, 1418-1426

Zhu, Y.G., Chen ,S.B., Yang, J.C. 2004. Effects of soil amendments on lead up take by two vegetable crop s from a lead - contaminated soil from Anhui, China. Environment International. 30, 351-356. 